九州大学学術情報リポジトリ

Kyushu University Institutional Repository

\title{
膀胱䅡部に金属リングを装着した低活動膀胱モデル の確立
}

エルジャマル，カリマン

http://hdl. hand le. net/2324/4475006

出版情報: Kyushu University，2020，博士（医学），課程博士 バージョン：

権利関係: Public access to the fulltext file is restricted for unavoidable reason (2) 
論文名： New mouse model of underactive bladder developed by placement of a metal ring around the bladder neck

(膀胱䅡部に金属リングを装着した低活動膀胱モデルの確立)

区 分：甲

$$
\text { 論 文 内容 の 要 旨 }
$$

目的：慢性膀胱出口部閉塞（BOO: Bladder Outlet Obstruction）によって引き起こされる低活動膀胱 (UAB) の新しいマウスモデルを開発することである。

方法 : BOO は、6 週齢のオスの C57BL / 6 マウスで、各マウスの膀胱頸部の周りに銀製のジャンプリ ングを緩く配置する手術を施行して作成した。代謝ケージを使用して排尿記録とマウス用シストメ トリで膀胱内圧測定を使用し、BOO 処置後の 8 週後と 16 週間後の膀胱機能を評価した。機能解析 後、マウスの膀胱を摘出し、重量を計測した後、組織学的解析を行った。

結果 : 排尿記録分析では、16 週間処置した BOO マウスは、8 週間処置した BOO マウスより一日排 尿回数（7.3 \pm 1.1 回/日 vs. $12.5 \pm 3.0$ 回/日、 $\mathrm{P}<0.05 ）$ が少なくなり、また、一回あたりの排尿量

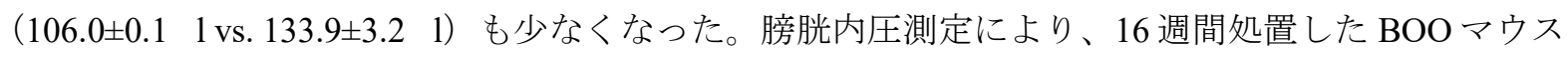

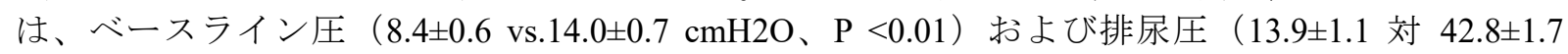
$\mathrm{cmH} 2 \mathrm{O} 、 \mathrm{P}<0.05)$ が低かったことが明らかとなった。時間の経過とともに膀胱の質量増加、及び、 とコラーゲンの沈着の増加が認められた。

結論 : 膀胱頸部に銀製のジャンプリングを緩く配置する手術を使用して、UAB の新しいマウスモデ ルを確立することに成功した。BOO は最初に過活動膀胱を誘発したが、その後、排尿筋平滑筋の収 縮性の低下と膀胱壁へのコラーゲンの進行性沈着によりUABを引き起こした。 